\title{
Exploring Neolithic and Megalithic south India: the Bellary District archaeological project
}

\author{
Nicole Boivin, Ravi Korisettar, P.C. Venkatasubbaiah, Helen Lewis, DeEPak HavanuR, \\ Kalyan Malagyannavar \& SubHas Chincholi*
}

The southern part of the Indian peninsula is an area of outstanding archaeological interest. While its historic cities and temples have long attracted the interest of both scholars and tourists, however, south India's equally remarkable prehistoric period remains have only rarely received the attention they deserve. A new joint Cambridge-Karnatak University research project was thus initiated in 2002 to study the unique Neolithic and Iron Age remains of the southern Deccan. This 2-month pilot project focused its efforts on the Bellary District of Karnataka, where prehistoric megaliths and 'ashmounds' (large mounds of burnt cattle dung) occupy a stunning landscape of naturally sculpted granitic rock formations (FIGURE 1). The aim of the project was to explore, survey and record visible archaeological and landscape features in order to acquire insights into the indigenous processes of neolithization and megalithism that led to the formation of these unique and still enigmatic monuments of ash and stone.

The Bellary project incorporated a range of approaches at different scales of analysis. One particular cluster of sites, known as SanganakalluKupgal, was selected for intensive exploration and survey. This included surface exploration and study of a variety of activity areas, including permanent and temporary habitation sites, stonequarrying and tool-production areas, rock-art sites, rock-shelters, ashmounds and megaliths. In addition, systematic fieldwalking was undertaken on the plain that surrounds the large granitic outcrops upon which most prehistoric activity seems to have focused. Fieldwalking tended to confirm this general south Deccan land-use pattern, since finds off the granitic tors were predominantly of the Early Historic and later periods. Nevertheless, several small rock-art sites and a rock-shelter rich in microliths and containing a partially exposed human burial were also discovered during this phase of the project.

Exploration of sites in the region surrounding Sanganakallu-Kupgal was also undertaken in order to investigate the relationships between archaeological and landscape features. This aspect of the project made use of theoretical concepts and methodological approaches that have not previously been applied in studies of south Indian prehistory, including symbolic and phenomenological approaches to understanding the perception and use of landscapes in the past. This research demonstrated that the location of sites, and particularly ashmound sites, was influenced by patterns of visibility and movement, the presence of visually dramatic landscape features and the east-west movement of the sun across the sky. It suggests that the evocative landscape of the southern Deccan was not just a backdrop for Neolithic activities, but rather a mythical and possibly sacred 'force' that permeated many aspects of Neolithic (and subsequent Megalithic/Iron Age) life.

Some preliminary efforts were also made to analyse the rock art found at Sanganakallu-Kupgal and other sites in the Bellary district. Rock-art motifs, predominantly in the form of pictographs, are found in remarkable quantities at SanganakalluKupgal. These are dominated by depictions of the long-horned, humped cattle that were domesticated during the southern Neolithic, but also include ithyphallic and dancing figures, and hunting, bull-capturing and sexual scenes, as well as apparently abstract motifs. The presence of remarkable 'ringing rocks' at Sanganakallu and other sites with large concentrations of rock-art motifs was also noted for the first time (see FIGURE 2). Combined with the fact that many motifs are visible only to the physically able (viewing them involves climbing rocks) and to small groups or individuals, these ringing rocks suggest that rock-art production and/or viewing was part of an overall ritualized sensory experience available only to a particular sector of society or even individual.

Several specifically targeted micro-scale investigations were also carried out at a number of sites in order to shed light on particular aspects of landscape use and perception. For example, micromorphological and bulk geoarchaeological sampling of exposed ashmound sections at three different sites was carried out with the aim of

\footnotetext{
* Boivin, McDonald Institute for Archeological Research, Downing Street, Cambridge CB2 3ER, England. nlb20@cus.cam.ac.uk Korisettar, Department of History \& Archaeology, Karnatak University, Dharwad, Karnataka 580003, India. korisettar@yahoo.com
}

ANTIQUITY 76 (2002): 937-8 


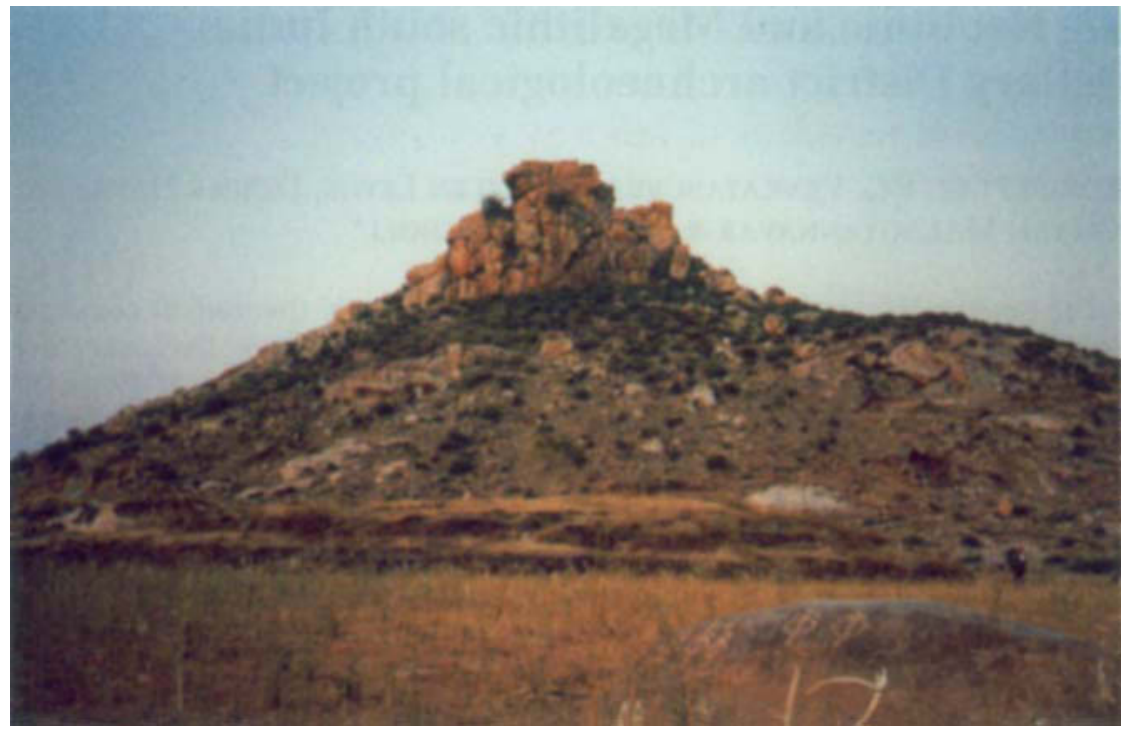

FIGURE 1 (left). Kupgal ashmound (note person at right for scale), with Hiregudda granitic outcrop in background and recent rock art in foreground (right).

FIGURE 2 (below, right), 'Ringing rocks' and ancient petroglyphs at Hiregudda, Sanganakallu.

FIGURE 3 (below, left). Legged terracotta sarcophagus and pots from the burial at Kudatini.

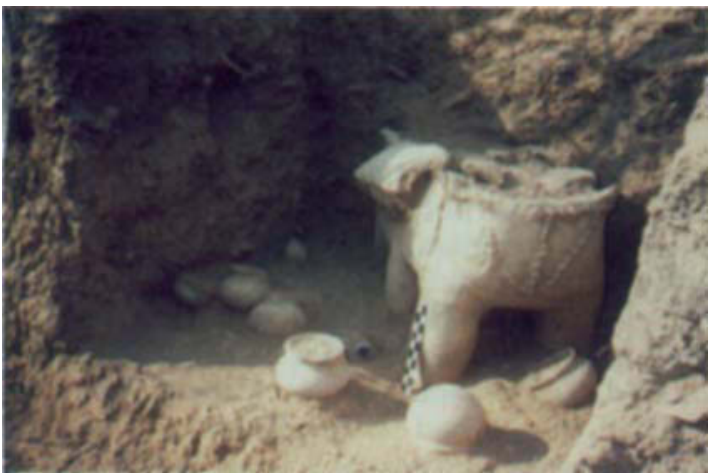

shedding light on processes of ashmound formation. In addition, small-scale excavation was carried out on a pit that had been partially exposed by recent construction activity at the largest known ashmound of Kudatini (located about $15 \mathrm{~km}$ west of Sanganakallu), revealing a six-legged zoomorphic sarcophagus of probable early Megalithic date (c. $1100 \mathrm{BC}$ ) (FIGURE 3). The terracotta sarcophagus, which was surrounded by at least 12 pots, some containing human bone, was oriented precisely north-south and contained a secondary child burial and a fine chert blade. The find is unique for this part of south India, and holds numerous implications, especially concerning continuity in certain aspects of landscape perception between the Neolithic and Megalithic periods.

It is intended to embark on a program of systematic excavation at Sanganakallu-Kupgal in future seasons, as well as to continue the training of local students in archaeological methods. Future efforts will also need to be directed towards obtaining protection for at least some of

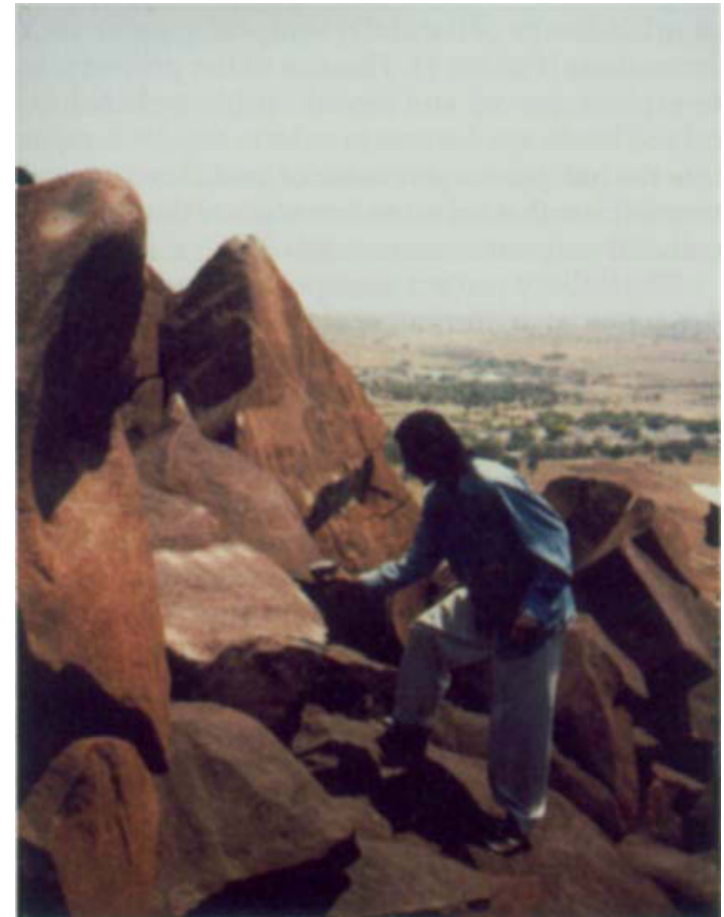

these remarkable sites, many of which are currently threatened with oblivion as a result of agricultural expansion and, particularly, large-scale commercial granite quarrying.

Acknowledgements. We wish to acknowledge the invaluable assistance of Ramadas and Linganna, both of Sanganatallu village. This project was funded by the British Academy, with additional aid coming from the Society for South Asian Studies, the Prehistoric Society and Karnatak University. 